3. Distal antennal joint about $.58 \mathrm{~mm}$. in length Myzocallis pasanice Davidson.

Distal antennal joint about $.34 \mathrm{~mm}$. in length 4 .

4. Distal sensorium of antennal III at or beyond middle of

joint Myzocallis californicus Baker.

Distal sensorium of antennal III hardly one-third of the length of the joint from base..................... Myzocallis californicus Baker var pallidus var nov.

Myzocallis californicus Baker var. pallidus var. nov.

This form differs from var californicus in the sensoriation of the third antennal joint, pallidus having 3 or 4 sensoria all in the basal third of the joint, whereas californicus has from 4 to 6 sensoria more widely distributed and occupying the basal half or more of the joint The structure of the body including the dorsal tubercles is very similar

Var pallidus is pale green in colour, smaller in body than californicus; it was collected January 5, 1918, on Quercus dumosa Nutt, an evergreen scrub oak, near Jacumba, Cal.

\title{
A NEW SPECIES OF THE GENUS TACHYDROMIA FROM ILLINOIS (DIPTERA, EMPIDIDA).
}

BY J. R. MALLOCH, URBANA, ILL.

The type series of the species described herein is deposited in the collection of the Illino is State Natural History Survey.

\section{Tachydromia harti, sp. n.}

Male and female.-Glossy dark brown. Head black; antennæ yellowish testaceous; palpi brown. Thorax brown, paler anteriorly; propleura with white pruinescence. Abdomen yellowish at base of venter. Legs yellowish testaceous, darker in female, hind femora and tibiæ except bases, mid tibix at bases, and apices of basal three and all of apical two joints of all tarsi in both sexes blackened; fore tibia in male with two deep black spots on the inner or anterior side, one, heart-shaped, beyond middle and the other, round, at apex. Wing with two broad, black fasciæ as in schrearai Coquillett, but the apical fascia extending nearer to apex of wing. Knobs of halteres white.

Eyes distinctly separated in both sexes; third antennal joint not large than second; arista terminal. Dorsum of thorax nude; scutellum with two bristles. Ventral sclerite of abdomen in male in front of hypopygium with a number of curved bristles, apex of hypopygium with a few similar bristles. Fore femur much swollen; fore tibia of male very much dilated from base to apex. Venation as in schwarzi.

Length $1.5-2 \mathrm{~mm}$.

Type-male, Havana, Ill., June 5, 1918, (J. R. Malloch). Allotype and paratypes topotypical. One male and three females.

This species is most closely allied to schwarzi Coquillett, but may be separated from it by the broadened fore tibia of the male and the very much closer approximation of the subapical fascia to the apex of the wing.

Named in honour of my late colleague, C. A. Hart, who did some of his best work in the locality where the species was taken.

November, 1919 